University of Nebraska - Lincoln

DigitalCommons@University of Nebraska - Lincoln

Publications from USDA-ARS / UNL Faculty

U.S. Department of Agriculture: Agricultural

Research Service, Lincoln, Nebraska

2012

\title{
Climate change alters stoichiometry of phosphorus and nitrogen in a semiarid grassland
}

Feike A. Dijkstra

The University of Sydney, feike.dijkstra@sydney.edu.au

Elise Pendall

University of Wyoming, pendall@uwyo.edu

Jack A. Morgan

USDA-ARS, Jack.Morgan@ars.usda.gov

Dana M. Blumenthal

USDA-ARS, Dana.Blumenthal@ars.usda.gov

Yolima Carrillo

The University of Sydney, Yolima.Carrillo@sydney.edu.au

See next page for additional authors

Follow this and additional works at: https://digitalcommons.unl.edu/usdaarsfacpub

Dijkstra, Feike A.; Pendall, Elise; Morgan, Jack A.; Blumenthal, Dana M.; Carrillo, Yolima; LeCain, Daniel R.; Follett, Ronald F.; and Williams, David G., "Climate change alters stoichiometry of phosphorus and nitrogen in a semiarid grassland" (2012). Publications from USDA-ARS / UNL Faculty. 1098.

https://digitalcommons.unl.edu/usdaarsfacpub/1098

This Article is brought to you for free and open access by the U.S. Department of Agriculture: Agricultural Research Service, Lincoln, Nebraska at DigitalCommons@University of Nebraska - Lincoln. It has been accepted for inclusion in Publications from USDA-ARS / UNL Faculty by an authorized administrator of DigitalCommons@University of Nebraska - Lincoln. 


\section{Authors}

Feike A. Dijkstra, Elise Pendall, Jack A. Morgan, Dana M. Blumenthal, Yolima Carrillo, Daniel R. LeCain, Ronald F. Follett, and David G. Williams 


\section{Climate change alters stoichiometry of phosphorus and nitrogen in a semiarid grassland}

\section{Feike A. Dijkstra ${ }^{1}$, Elise Pendall ${ }^{2}$, Jack A. Morgan ${ }^{3}$, Dana M. Blumenthal ${ }^{3}$, Yolima Carrillo ${ }^{1}$, Daniel R. LeCain ${ }^{3}$, Ronald F. Follett ${ }^{4}$ and David G. Williams ${ }^{5}$}

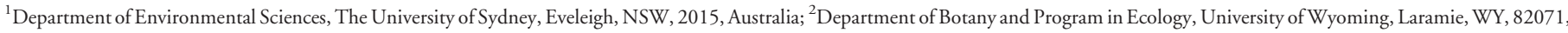

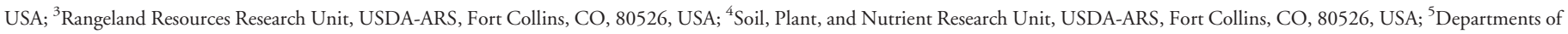
Botany, Ecosystem Science and Management, Program in Ecology, University of Wyoming, Laramie, WY, 82071, USA

Author for correspondence:

Feike A. Dijkstra

Tel: +61286271122

Email: feike.dijkstra@sydney.edu.au

Received: 23 July 2012

Accepted: 22 August 2012

New Phytologist (2012) 196: 807-815 doi: $10.1111 /$ j.1469-8137.2012.04349.x

Key words: elevated carbon dioxide, grasslands, homeostasis, N : P stoichiometry, nutrient availability, PHACE, soil moisture, temperature.

\section{Summary}

- Nitrogen $(\mathrm{N})$ and phosphorus $(\mathrm{P})$ are essential nutrients for primary producers and decomposers in terrestrial ecosystems. Although climate change affects terrestrial $\mathrm{N}$ cycling with important feedbacks to plant productivity and carbon sequestration, the impacts of climate change on the relative availability of $\mathrm{N}$ with respect to $\mathrm{P}$ remain highly uncertain.

- In a semiarid grassland in Wyoming, USA, we studied the effects of atmospheric $\mathrm{CO}_{2}$ enrichment (to $600 \mathrm{ppmv}$ ) and warming $\left(1.5 / 3.0^{\circ} \mathrm{C}\right.$ above ambient temperature during the day/night) on plant, microbial and available soil pools of $\mathrm{N}$ and $\mathrm{P}$.

- Elevated $\mathrm{CO}_{2}$ increased $\mathrm{P}$ availability to plants and microbes relative to that of $\mathrm{N}$, whereas warming reduced $\mathrm{P}$ availability relative to $\mathrm{N}$. Across years and treatments, plant $\mathrm{N}$ : $\mathrm{P}$ ratios varied between 5 and 18 and were inversely related to soil moisture.

- Our results indicate that soil moisture is important in controlling P supply from inorganic sources, causing reduced $\mathrm{P}$ relative to $\mathrm{N}$ availability during dry periods. Both wetter soil conditions under elevated $\mathrm{CO}_{2}$ and drier conditions with warming can further alter $\mathrm{N}: \mathrm{P}$. Although warming may alleviate $\mathrm{N}$ constraints under elevated $\mathrm{CO}_{2}$, warming and drought can exacerbate $\mathrm{P}$ constraints on plant growth and microbial activity in this semiarid grassland.

\section{Introduction}

Ongoing increases in atmospheric $\mathrm{CO}_{2}$ and temperature have large effects on carbon $(\mathrm{C})$ and nutrient cycles in terrestrial ecosystems, with potentially strong feedbacks to the global climate system (Heimann \& Reichstein, 2008). Much attention has been given to $\mathrm{CO}_{2}$ and temperature effects on the nitrogen $(\mathrm{N})$ cycle because of its importance for plant growth, $\mathrm{C}$ sequestration and biodiversity (An et al., 2005; Reich, 2009; Niu et al., 2010; Norby et al., 2010). Elevated $\mathrm{CO}_{2}$ often results in reduced $\mathrm{N}$ availability to plants, as increased plant growth stimulates plant $\mathrm{N}$ uptake and immobilization in long-lived plant biomass, and increased soil C stimulates microbial N immobilization in the soil (Luo et al., 2004). Reduced soil $\mathrm{N}$ availability may eventually dampen the stimulatory effect of elevated $\mathrm{CO}_{2}$ on plant growth (Luo et al., 2004; Norby et al., 2010). An increase in temperature, however, often increases $\mathrm{N}$ availability to plants, because increased microbial activity in the soil releases $\mathrm{N}$ from organic matter (Rustad et al., 2001; Melillo et al., 2002), which, in turn, can offset the immobilization effect of elevated $\mathrm{CO}_{2}$ (Hovenden et al., 2008).

Plant growth and microbial activity in terrestrial ecosystems are also often affected by phosphorus (P) availability (Güsewell, 2004; Cleveland \& Liptzin, 2007; Elser et al., 2007). In most soils, $\mathrm{N}$ is supplied through biological $\mathrm{N}$ fixation and atmospheric deposition, whereas the primary source of $\mathrm{P}$ is rock weathering. Both nutrients are recycled through soil organic matter decomposition. $\mathrm{N}$ limitation often occurs in young soils with limited accumulation of atmospheric $\mathrm{N}$ input (Vitousek \& Farrington, 1997), or in systems with high $\mathrm{N}$ loss through nitrification and denitrification processes, fires and leaching (Vitousek \& Howarth, 1991). P limitation often occurs in old soils in which $\mathrm{P}$ is no longer supplied through weathering, or in soils with high $\mathrm{P}$ sorption/precipitation capacity (Walker \& Syers, 1976; Vitousek \& Howarth, 1991). Primary productivity in terrestrial ecosystems is therefore frequently limited by both $\mathrm{N}$ and $\mathrm{P}$ in soils of intermediate age (Vitousek \& Farrington, 1997) or when the availability of both nutrients is low (Harpole et al., 2011). Indeed, the limitation of both $\mathrm{N}$ and $\mathrm{P}$ on primary productivity is widespread in terrestrial ecosystems (Güsewell, 2004; Elser et al., 2007; Craine et al., 2008; Craine \& Jackson, 2010; Harpole et al., 2011).

The availability of $\mathrm{P}$ as well as $\mathrm{N}$ may be altered by elevated $\mathrm{CO}_{2}$ and warming, potentially causing shifts in $\mathrm{N}$ and $\mathrm{P}$ supplied to plants. Although the release of both nutrients is biologically controlled through the mineralization of soil organic matter by microbes, $\mathrm{P}$ availability is also controlled geochemically through sorption/desorption and dissolution/precipitation reactions (Achat 
et al., 2009; Yang \& Post, 2011). Elevated $\mathrm{CO}_{2}$ and warming effects on these biotic and abiotic processes could alter the relative supply of $\mathrm{N}$ and $\mathrm{P}$, and eventually cause changes in primary productivity, soil organic matter decomposition and biodiversity (Güsewell, 2004; Wassen et al., 2005; Güsewell \& Gessner, 2009; Liu et al., 2010).

Plants and microbes require $\mathrm{N}$ and $\mathrm{P}$ in specific ratios for optimal growth and have limited flexibility to take up $\mathrm{N}$ and $\mathrm{P}$ under conditions of variable and often unbalanced $\mathrm{N}$ and $\mathrm{P}$ availability. Perturbations affecting the relative availability of $\mathrm{N}$ and $\mathrm{P}$ may have different impacts on plant growth and microbial activity because of their dissimilar requirements for $\mathrm{N}$ and $\mathrm{P}$. For instance, microbial $\mathrm{N}: \mathrm{P}$ ratios tend to be lower than plant N : P ratios (Cleveland \& Liptzin, 2007), suggesting that the demand for $P$ relative to $N$ is greater for microbes than for plants. Furthermore, plant species differ in their stoichiometric homeostasis in the $\mathrm{N}: \mathrm{P}$ ratio, or in their ability to maintain a constant $\mathrm{N}$ : P ratio under variable supply of both nutrients (Sterner \& Elser, 2002; Güsewell, 2004). The maintenance of stoichiometric homeostasis in environments with variable nutrient supply is energetically expensive for plants (Sterner \& Elser, 2002). Thus, environments with temporally variable nutrient supply may favour species that are flexible in their N : P stoichiometry (Sardans et al., 2012). The importance of stoichiometric $\mathrm{N}$ : P flexibility in plant growth responses to climate change is unknown.

In this study, we examine how elevated $\mathrm{CO}_{2}$ and warming affect $\mathrm{N}$ and $\mathrm{P}$ cycling in a semiarid grassland in Wyoming, USA with low $\mathrm{N}$ and $\mathrm{P}$ availability. We include an irrigation treatment to study the direct effects of soil water availability on $\mathrm{N}$ and $\mathrm{P}$ cycling. Previously, we have demonstrated that elevated $\mathrm{CO}_{2}$ increases significantly soil moisture as a result of reductions in plant stomatal conductance, and that warming decreases significantly soil moisture as a result of desiccation effects at this site (Morgan et al., 2011). Consequently, warming induces more extreme soil moisture conditions (i.e. faster and more severe soil drying after rainfall events), whereas elevated $\mathrm{CO}_{2}$ dampens soil moisture extremes. The $\mathrm{C} 3$ grasses at this site respond most strongly to elevated $\mathrm{CO}_{2}$, whereas the $\mathrm{C} 4$ grasses also respond to warming. Further, we have shown that soil $\mathrm{N}$ availability decreases with elevated $\mathrm{CO}_{2}$ and increases with warming (Dijkstra et al., 2010; Carrillo et al., 2012). Here, we build on this work by examining $\mathrm{P}$ and $\mathrm{N}: \mathrm{P}$ in plants, microbes and soils. The objectives of this study were to examine how elevated $\mathrm{CO}_{2}$ and warming affect plant, microbial and available pools of $\mathrm{N}$ and $\mathrm{P}$ in the soil; how $\mathrm{N}$ and $\mathrm{P}$ dynamics are related to soil moisture; and how stoichiometric flexibility in plant $\mathrm{N}$ : P relates to changes in plant growth among individual species in response to elevated $\mathrm{CO}_{2}$ and warming.

\section{Materials and Methods}

The Prairie Heating And $\mathrm{CO}_{2}$ Enrichment (PHACE) experiment is located at the US Department of Agriculture Agricultural Research Service High Plains Grasslands Research Station, Wyoming, USA (latitude $41^{\circ} 11^{\prime} \mathrm{N}$, longitude $104^{\circ} 54^{\prime} \mathrm{W}$ ). The ecosystem is a northern mixed-grass prairie dominated by the cool-season C3 grasses Pascopyrum smithii (Rydb.) A. Love and
Hesperostipa comata Trin and Rupr., and the warm-season C4 grass Bouteloua gracilis (H.B.K) Lag. Other species include the sedge Carex eleocharis L. Bailey and the forb Sphaeralcea coccinea (Nutt.) Rydb. These five species comprise between 80 and $99 \%$ of the total aboveground biomass. The mean annual precipitation is $384 \mathrm{~mm}$ and the mean air temperatures are $17.5^{\circ} \mathrm{C}$ in July and $-2.5^{\circ} \mathrm{C}$ in January. The soil is a fine loamy, mixed, mesic Aridic Argiustoll with a $\mathrm{pH}$ of 7.0 , bulk density of $1.2 \mathrm{~g} \mathrm{~cm}^{-3}, 62 \%$ sand, $23 \%$ silt and $15 \%$ clay. The calcareous soil contains substantial amounts of solid inorganic P (calcium phosphates), forming $42 \%$ of total soil $\mathrm{P}$, whereas almost all soil $\mathrm{N}$ is in organic form (Table 1).

The core experiment consists of 20 circular plots (each $3.4 \mathrm{~m}$ in diameter) with two atmospheric $\mathrm{CO}_{2}$ concentration levels (ambient and $600 \mathrm{ppmv}$ ) and two temperature levels (ambient and $1.5 /$ $3.0^{\circ} \mathrm{C}$ above ambient temperature during the day/night) in a full factorial design (five replicates for each treatment combination). The experiment uses Free-Air $\mathrm{CO}_{2}$ Enrichment, or FACE, technology to raise the $\mathrm{CO}_{2}$ concentration, and ceramic infrared heaters with a proportional-integral-derivative feed-back loop to raise the canopy temperature. The $\mathrm{CO}_{2}$ treatment began in April 2006 and the warming treatment in April 2007. The experiment includes five extra plots that are kept under ambient $\mathrm{CO}_{2}$ and temperature conditions, but with $60 \mathrm{~mm} \mathrm{yr}^{-1}$ of irrigation applied in three to four events during the growing season. This amount of added water increased the soil moisture content to levels approximating those observed in plots exposed to elevated $\mathrm{CO}_{2}$. The volumetric soil moisture content was continuously monitored in all plots at a soil depth of $10 \mathrm{~cm}$ (Sentek Envirosmart sensors, Sentek Sensor Technologies, Stepney, SA, Australia). Detailed information about the site and experiment has been reported elsewhere (Dijkstra et al., 2010; Morgan et al., 2011).

Aboveground plant biomass was clipped in mid-July of 2007, 2008 and 2009 at peak biomass. A metal grid containing 24 quadrats $\left(25 \mathrm{~cm} \times 25 \mathrm{~cm}\right.$; total of $\left.1.5 \mathrm{~m}^{2}\right)$ was placed inside the plots, and vegetation in every other quadrat (12 in total) was clipped to the crown. Aboveground biomass was separated by green and senesced biomass. Green biomass was further separated by species (senesced biomass could not be identified by species). We analysed $\mathrm{N}$ and $\mathrm{P}$ on senesced plant tissue and green tissue of the five species mentioned above. Samples were dried $\left(60^{\circ} \mathrm{C}\right)$, weighed and ground, and then analysed for $\mathrm{N}$ concentration on an elemental analyser (Carlo Erba, Haake Buchler Instruments, Saddle Brook, NJ, USA). Subsamples were ashed before colorimetric P analysis using the ammonium molybdate-vanadate reagent (Jackson, 1958) on a spectrophotometer (Bausch and Lomb, Rochester, NY, USA). In 2007 and 2009, Plant Root Simulator (PRS) resin

Table 1 Soil C, N and P pools at a soil depth of $0-15 \mathrm{~cm}$ in the Prairie Heating And $\mathrm{CO}_{2}$ Enrichment (PHACE) experiment in the control plots ( $\pm \mathrm{SE}$ )

\begin{tabular}{|c|c|c|c|c|c|}
\hline \multirow[b]{2}{*}{ Pool } & \multirow{2}{*}{$\begin{array}{l}\text { Total } \\
\mathrm{g} \mathrm{m}^{-2}\end{array}$} & \multicolumn{2}{|c|}{ Organic form } & \multicolumn{2}{|c|}{ Inorganic form } \\
\hline & & $\mathrm{g} \mathrm{m}^{-2}$ & $\%$ of total & $\mathrm{g} \mathrm{m}^{-2}$ & $\%$ of total \\
\hline $\mathrm{C}$ & 2989 (168) & $2945(167)$ & 98.5 & 44 (19) & 1.5 \\
\hline $\mathrm{N}$ & $256(14)$ & $256(14)$ & 99.8 & $0.4(0.03)$ & 0.2 \\
\hline$P$ & $64.4(2.2)$ & $38.3(2.1)$ & 59 & $26.1(0.6)$ & 41 \\
\hline
\end{tabular}


probes (Western Ag Innovations, Saskatoon, CA, USA) were used to measure the availability of $\mathrm{N}$ and $\mathrm{P}$ in the soil (at $2-7.6 \mathrm{~cm}$ soil depth) during the growing season (May-October). After retrieval, probes were washed with deionized water and sent to Western $\mathrm{Ag}$ Innovations for analyses. Probes were extracted with $0.5 \mathrm{~N} \mathrm{HCl}$ solution and the extractant was analysed for $\mathrm{NH}_{4}^{+}$and $\mathrm{NO}_{3}^{-}$ colorimetrically on a flow injection analyser (Seal Analytical, Mequon, WI, USA) and for P using inductively coupled plasma emission spectroscopy (Perkin Elmer, Inc., Waltham, MA, USA). These probes provide a nondestructive integrative index of available $\mathrm{N}$ and $\mathrm{P}$ to plants during the period for which they are in the soil (Johnson et al., 2007). Because only inorganic, and not organic, forms of $\mathrm{N}$ and $\mathrm{P}$ (nitrate, ammonium and inorganic phosphate) were measured, available $\mathrm{N}$ and $\mathrm{P}$ may have been underestimated. Although plants are capable of taking up organic $\mathrm{N}$ as amino acids that are present in many soils (Hofmockel et al., 2010), it remains unclear how important organic $\mathrm{N}$ uptake is for plant nutrition (Näsholm et al., 2009). Even less clear is the importance of organic P uptake (Macklon et al., 1994). In 2005, before experimental treatments started, soils were sampled in each plot from 0 to 5 and 5 to $15 \mathrm{~cm}$ soil depth, and analysed for bulk density and inorganic $\mathrm{C}$ as carbonates (Sherrod et al., 2002).

In 2009, soils were sampled $1 \mathrm{wk}$ after the aboveground biomass sampling in each plot at the same depths as in 2005. After inorganic $\mathrm{C}$ had been removed with $1 \mathrm{M} \mathrm{H}_{3} \mathrm{PO}_{4}$, soils were analysed for total organic $\mathrm{C}$ and $\mathrm{N}$ on an elemental analyser. Total organic and inorganic $\mathrm{P}$ were analysed using the ignition $-0.2 \mathrm{~N} \mathrm{H}_{2} \mathrm{SO}_{4}$ extraction method (Saunders \& Williams, 1955) with subsequent colorimetric measurement of $\mathrm{P}$ in the extracts using the ammonium molybdate-vanadate reagent. Soil subsamples were extracted with $0.05 \mathrm{M} \mathrm{K}_{2} \mathrm{SO}_{4}$ and analysed for inorganic $\mathrm{N}\left(\mathrm{NH}_{4}^{+}\right.$and $\left.\mathrm{NO}_{3}^{-}\right)$on a flow injection analyser (Lachat Instruments, Loveland, CO, USA). Microbial $\mathrm{C}, \mathrm{N}$ and $\mathrm{P}$ were measured using the fumigationextraction method (Brookes et al., 1982, 1985). Soil subsamples were fumigated with chloroform for $5 \mathrm{~d}$ and, together with nonfumigated subsamples, were extracted with $0.05 \mathrm{M} \mathrm{K}_{2} \mathrm{SO}_{4}$ for $\mathrm{C}$ and $\mathrm{N}$ analyses on a total organic $\mathrm{C}$ analyser (Shimadzu Scientific Instruments, Wood Dale, IL, USA) and with $0.5 \mathrm{M} \mathrm{NaHCO}_{3}$ for colorimetric $\mathrm{P}$ analysis using the ammonium molybdate-ascorbic acid reagent (Olsen \& Sommers, 1982). To correct for P sorption during fumigation and extraction, five off-plot samples were spiked with $100 \mu \mathrm{g}$ P and similarly analysed for P (Brookes et al., 1982). We used $0.45,0.54$ and 0.4 extraction efficiency corrections for $\mathrm{C}$, $\mathrm{N}$ and $\mathrm{P}$, respectively, to calculate microbial C, N and P. Although these sorption and extraction efficiency correction factors are soil type dependent (e.g. soil texture), we do not expect them to be affected by the treatments of our experiment. All soil measurements were expressed per unit area using the bulk density measurements conducted in 2005 and by combining the two soil depths. Detailed methods for plant, PRS probe and soil $\mathrm{N}$ analyses are provided elsewhere (Dijkstra et al., 2010; Morgan et al., 2011).

The degree of homeostasis, or the $\mathrm{H}$ factor, was calculated by plotting the log-transformed values of green plant $\mathrm{N}$ : P and PRS probe $\mathrm{N}$ : P from each of the 20 core plots measured in 2007 and 2009 , where the $\mathrm{H}$ factor is the inverse of the slope (Sterner \& Elser, 2002): $\log ($ green plant $\mathrm{N}: \mathrm{P})=a+(1 / H) \log (\mathrm{PRS}$ probe $\mathrm{N}: \mathrm{P})$

We used ANOVA to test for the main effects of $\mathrm{CO}_{2}$ and warming and their interactive effect on plant, PRS probe and microbial N, P and N : P in each year using the 20 core plots. To test whether the five species differed in their stoichiometric flexibility $(\log ($ green plant $\mathrm{N}: \mathrm{P}))$ to relative changes in available $\mathrm{N}$ and $\mathrm{P}$ in the soil $(\log (\mathrm{PRS}$ probe $\mathrm{N}: \mathrm{P})$, we used ANCOVA with species as a main effect, $\log (\mathrm{PRS}$ probe $\mathrm{N}: \mathrm{P})$ as a covariate and their interaction. We used ANOVA to test for irrigation effects on plant, PRS probe and microbial N, P and N:P in each year, comparing the five ambient $\mathrm{CO}_{2}$ and temperature plots with the five irrigated plots. We used linear and nonlinear regressions to test for relationships between soil moisture and plant N, P and N : P ratios, and among $\mathrm{N}: \mathrm{P}$ ratios in soil organic matter, microbes, plants and PRS probes. In some cases, data were log transformed to improve the assumptions of normality and homoscedasticity. All statistical analyses were performed with JMP (version 4.0.4; SAS Institute, Cary, NC, USA).

\section{Results}

The climate change treatments at PHACE altered the balance of available nutrients in soil and in plant and microbial biomass pools (Fig. 1). In general, elevated $\mathrm{CO}_{2}$ decreased $\mathrm{N}: \mathrm{P}$ ratios in aboveground plant biomass (Fig. 1a,b). Warming increased $\mathrm{N}: \mathrm{P}$ ratios, particularly in 2008 and 2009, although the warming effect was not as strong as the elevated $\mathrm{CO}_{2}$ effect. Elevated $\mathrm{CO}_{2}$ and warming had similar effects on the $\mathrm{N}: \mathrm{P}$ ratios of the plant species $B$. gracilis, $H$. comata and $P$. smithii, but did not alter significantly the N:P ratios of the less abundant species C.eleocharis and S. coccinea (Supporting Information Table S1). The N : P ratios measured in green plant biomass were always smaller than in senesced plant biomass, indicating that the resorption of $\mathrm{P}$ was greater relative to that of $\mathrm{N}$. Warming increased microbial $\mathrm{N}: \mathrm{P}$ in 2009, particularly under ambient $\mathrm{CO}_{2}$ (Fig. 1c). The $\mathrm{N}: \mathrm{P}$ ratio of available $\mathrm{N}$ and $\mathrm{P}$ in the soil, measured with the PRS resin probes for the 2007 and 2009 growing seasons, decreased with elevated $\mathrm{CO}_{2}$ (Fig. 1d).

Treatment effects on $\mathrm{N}$ : P stoichiometry were sometimes caused by changes in $\mathrm{N}$, sometimes by changes in $\mathrm{P}$, and were sometimes only expressed by simultaneous changes in $\mathrm{N}$ and $\mathrm{P}$ (Tables S2S4). For example, although treatment effects on green plant $\mathrm{N}$ : $\mathrm{P}$ were caused by changes in N concentration in 2007 and 2008, they were caused by changes in P concentration in 2009 (Table S2). Warming increased the green plant $\mathrm{N}$ pool for the five dominant species in all $3 \mathrm{yr}(P<0.05$ in 2008 and $P<0.1$ in 2007 and 2009), as reported previously for all species combined (Dijkstra etal., 2010; Carrillo et al., 2012), but had no effect on the green plant $\mathrm{P}$ pool (Table S3). Elevated $\mathrm{CO}_{2}$ had no effect on the green plant $\mathrm{N}$ and $\mathrm{P}$ pools of the five dominant species. However, the highest $\mathrm{P}$ amounts were observed in the CT treatment (see Fig. 1 for definition), causing a marginally significant $\mathrm{CO}_{2} \times$ temperature interactive effect in 2009. Elevated $\mathrm{CO}_{2}$ decreased the available $\mathrm{N}$ measured by the PRS probes in both 2007 and 2009, but had no effect on available P (Table S4). Warming increased available $\mathrm{N}$ 


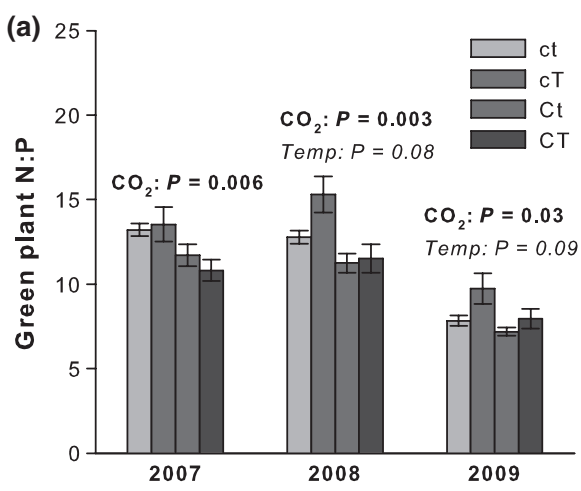

(c)

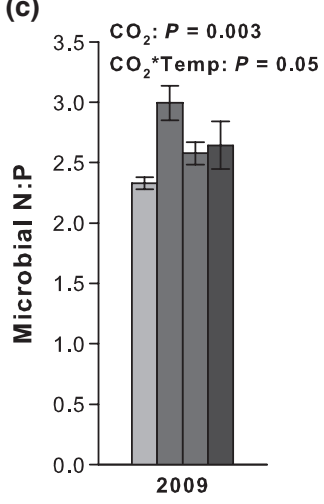

(d)

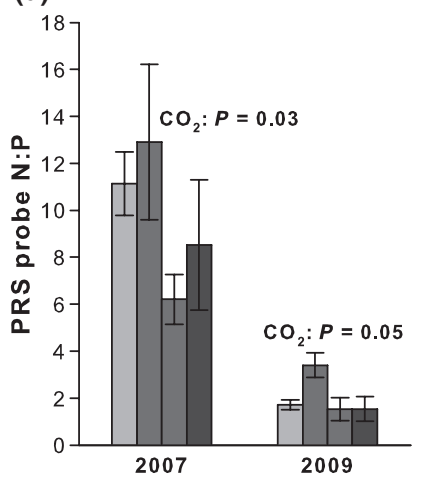

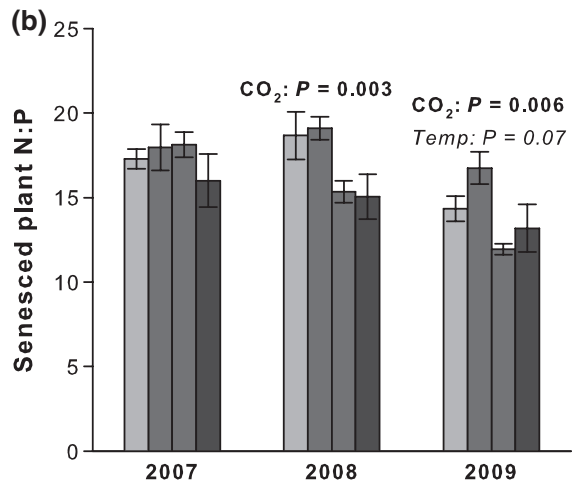

(e)

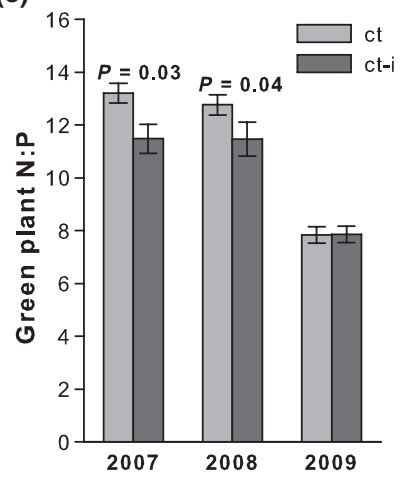

Fig. $1 \mathrm{~N}$ : $\mathrm{P}$ ratios in green $(\mathrm{a}, \mathrm{e})$ and senesced (b) plant tissue, microbes (c) and on Plant Root Simulator resin probes (PRS probes) (d) in response to elevated $\mathrm{CO}_{2}$, warming and irrigation (ct, ambient $\mathrm{CO}_{2}$ and temperature; $\mathrm{CT}$, ambient $\mathrm{CO}_{2}$ and $1.5 / 3^{\circ} \mathrm{C}$ day/night warming; $\mathrm{Ct}, 600$ ppmv $\mathrm{CO}_{2}$ and ambient temperature; $\mathrm{CT}, 600 \mathrm{ppmv} \mathrm{CO}_{2}$ and $1.5 / 3^{\circ} \mathrm{C}$ day/night warming; ct-i, ambient $\mathrm{CO}_{2}$ and temperature with $60 \mathrm{~mm} \mathrm{yr}^{-1}$ irrigation). Green plant N : $\mathrm{P}$ ratios are species-weighted averages. Error bars represent 1SE. ANOVA $P$ values are reported when $P<0.05$ (in bold) or $P<0.1$ (in italics). in both years, and also increased available P in 2007, but not to the same extent as $\mathrm{N}$. Treatment effects on microbial $\mathrm{N}$ : P were caused by simultaneous changes in microbial $\mathrm{N}$ and $\mathrm{P}$ (Table S4). Elevated $\mathrm{CO}_{2}$ caused a marginally significant increase in the microbial $\mathrm{N}: \mathrm{C}$ ratio (reflecting an increase in microbial $\mathrm{N}$ concentration), whereas warming reduced both the microbial $\mathrm{P}$ : $\mathrm{C}$ ratio (or microbial $\mathrm{P}$ concentration) and $\mathrm{P}$ amount.

The irrigation treatment decreased plant N : P ratios in 2007 and 2008, similar to that observed with elevated $\mathrm{CO}_{2}$, but not during the relatively wet year of 2009 when annual precipitation was $17 \%$ higher than the 132-yr mean for this site (Fig. 1e). In that relatively wet year, plant and PRS probe $\mathrm{N}$ : P ratios were lower than in the two previous years when precipitation was within $7 \%$ of the longterm mean. The PRS probe $\mathrm{N}: \mathrm{P}$ ratios varied between 0.1 and 25 , whereas the green plant $\mathrm{N}: \mathrm{P}$ ratios varied between 5 and 18 across the $\mathrm{CO}_{2}$ and warming treatments and years. Further, PRS probe and green plant $\mathrm{N}: \mathrm{P}$ ratios were negatively related to mean earlyseason soil moisture content measured at a soil depth of $10 \mathrm{~cm}$ (Fig. 2a,b). For the PRS probes, this negative relationship was caused by a decrease in $\mathrm{N}$ with increased soil moisture, whereas, for plants, this was caused by both a decrease in plant $\mathrm{N}$ concentration and an increase in plant $\mathrm{P}$ concentration with increased soil moisture (Fig. 2c-f). Green plant $\mathrm{N}$ content was not related to soil moisture, but green plant $\mathrm{P}$ content increased significantly with increased soil moisture (Fig. 2g,h).

We observed a significant positive relationship between microbial and green plant $\mathrm{N}: \mathrm{P}$ and between microbial and PRS probe $\mathrm{N}: \mathrm{P}$ measured in 2009 (Fig. 3). Microbial N:P ratios were much smaller than green plant $\mathrm{N}$ : P ratios, suggesting that $\mathrm{P}$ requirements relative to $\mathrm{N}$ were larger for microbes than for plants. However, the
PRS probe $\mathrm{N}: \mathrm{P}$ ratios measured in 2009 were similar to the microbial $\mathrm{N}: \mathrm{P}$ ratios. Microbial $\mathrm{N}: \mathrm{P}$ ratios were not related to total soil organic matter $\mathrm{N}: \mathrm{P}$ ratios $(P>0.1$, data not shown).

The $\mathrm{N}: \mathrm{P}$ ratios of individual plant species were responsive to changes in the relative availability of $\mathrm{N}$ and $\mathrm{P}$ in the soil measured in 2007 and 2009 in the 20 core plots (Fig. 4). The five species measured showed a variable degree of stoichiometric flexibility or homeostasis, with the C4 grass $B$.gracilis showing the greatest flexibility (least homeostatic) to relative changes in available $\mathrm{N}$ and $P$ in the soil, and the C3 grass P. smithii showing the least flexibility (most homeostatic). The slopes of the relationships shown in Fig. 3 between soil-available and plant $\mathrm{N}: \mathrm{P}$ ratios were significantly different among the five species (interactive effect of species $\times \log$ (PRS probe $\mathrm{N}: \mathrm{P}$ ) in ANCOVA, $P=0.03$ ), and the $\mathrm{H}$ values, a measure of the degree of homeostasis (Sterner \& Elser, 2002), ranged between 4.3 and 9.6. Despite this range, we did not observe consistent relationships between species-specific $\mathrm{H}$ values and plant growth responses to elevated $\mathrm{CO}_{2}$ and warming.

\section{Discussion}

In general, soil-available, plant and microbial $\mathrm{N}: \mathrm{P}$ ratios decreased under elevated $\mathrm{CO}_{2}$ and increased with warming. We found strong evidence that the opposing effects of elevated $\mathrm{CO}_{2}$ and warming on available $\mathrm{N}:$ P to plants and microbes were driven by variations in soil moisture. Elevated $\mathrm{CO}_{2}$ increased soil moisture as a result of reductions in plant stomatal conductance, whereas the desiccating effect of warming decreased soil moisture (Morgan et al., 2011). Soil moisture control on soil-available and plant $\mathrm{N}: \mathrm{P}$ ratios was supported by lower $\mathrm{N}: \mathrm{P}$ ratios with irrigation, lower $\mathrm{N}: \mathrm{P}$ ratios in 
New
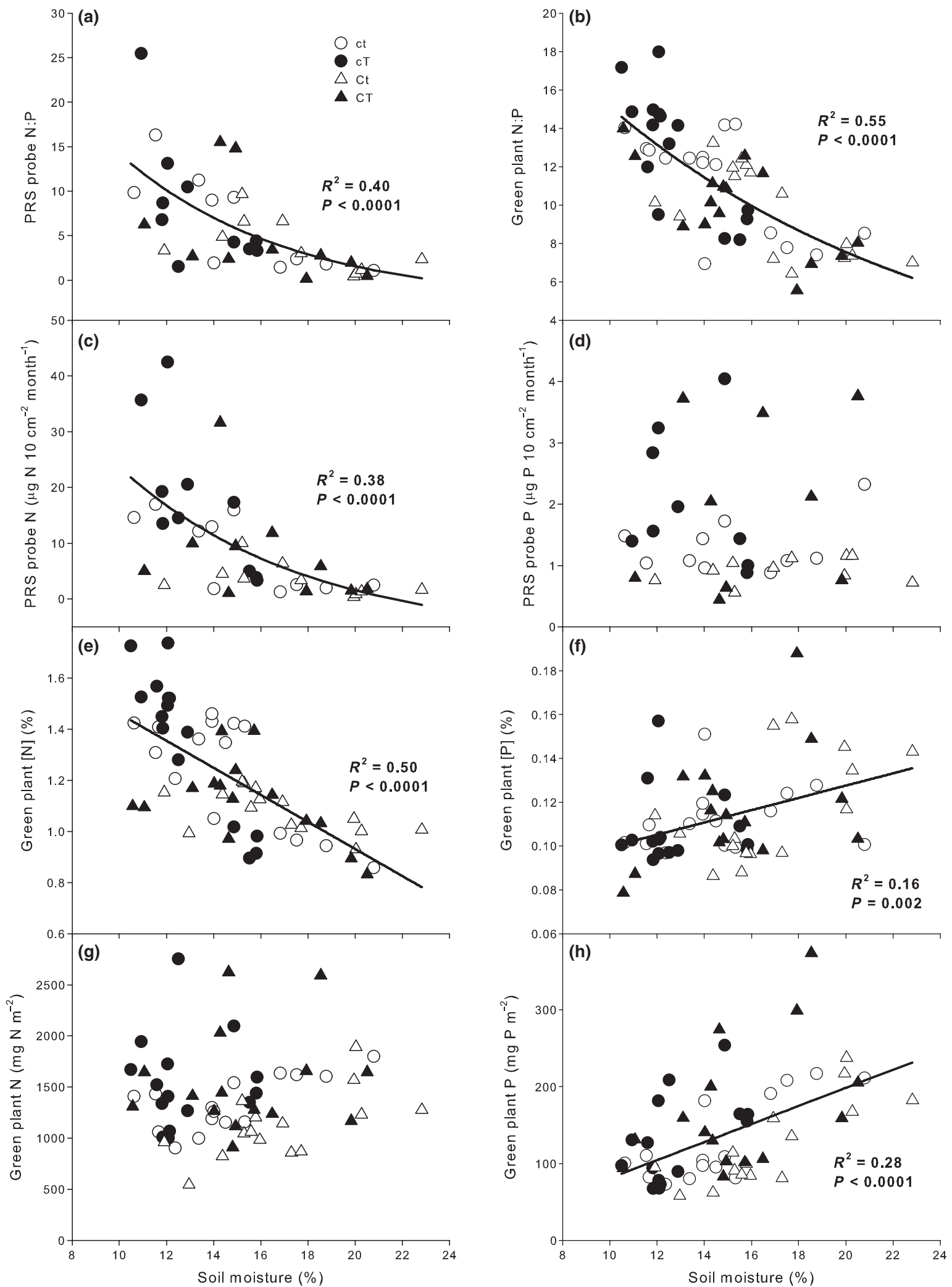

Fig. 2 Relationships between soil moisture and N : P ratios on the Plant Root Simulator (PRS) probes (a) and in green plants (b), N (c) and P (d) contents on PRS probes, N (e) and P ( $f$ ) concentrations in green plant tissue, and green plant N (g) and P (h) pools. Relationships are shown for the speciesweighted average and volumetric soil moisture at a soil depth of $10 \mathrm{~cm}$, averaged over days of year (DOY) 100-200. Each point represents a specific plot measured in 2007, 2008 and 2009 (2007 and 2009 for PRS probes). Treatments: ct, ambient $\mathrm{CO}_{2}$ and temperature; $\mathrm{cT}^{\circ}$ ambient $\mathrm{CO}_{2}$ and $1.5 / 3^{\circ} \mathrm{C}$ day/night warming; $\mathrm{Ct}, 600$ ppmv $\mathrm{CO}_{2}$ and ambient temperature; $\mathrm{CT}, 600 \mathrm{ppmv} \mathrm{CO}_{2}$ and $1.5 / 3^{\circ} \mathrm{C}$ day/night warming. 

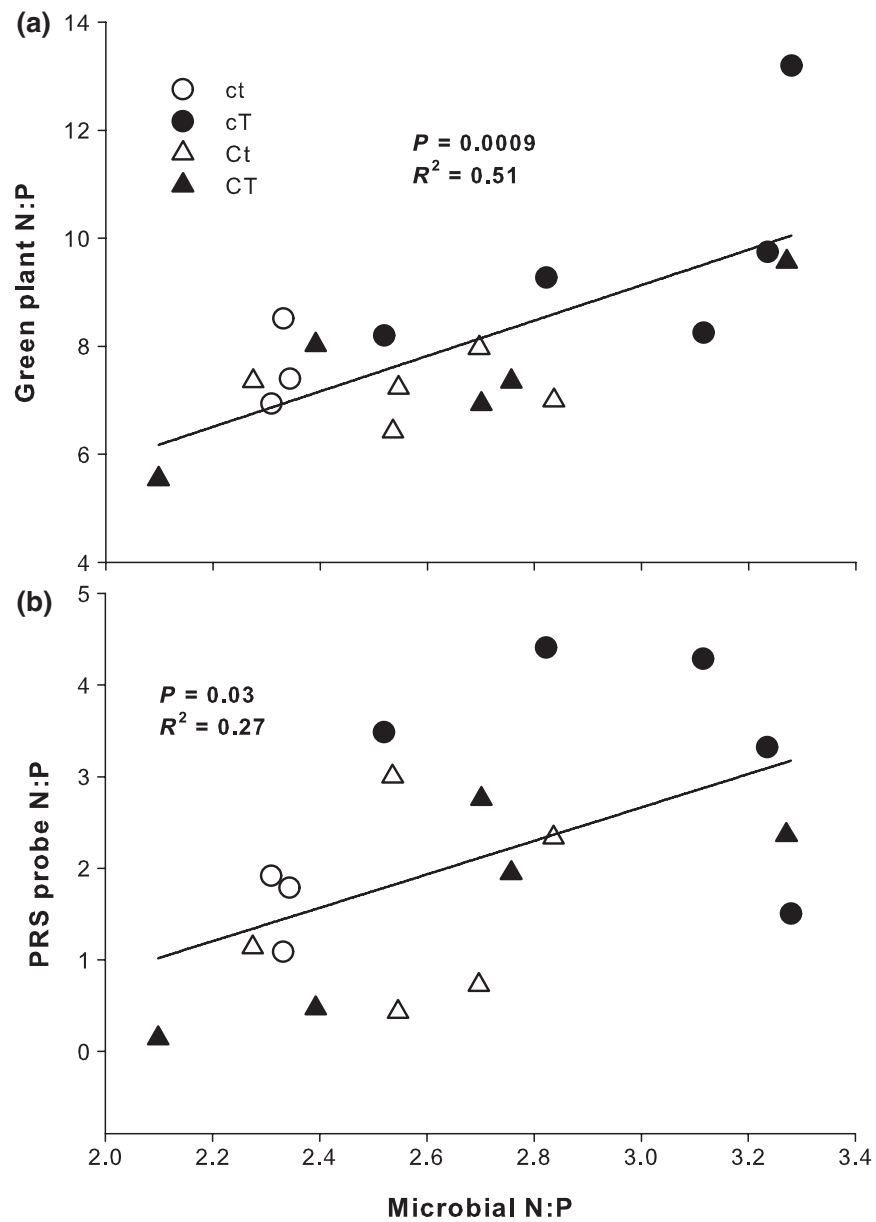

Fig. 3 Green plant N : P (a) and Plant Root Simulator (PRS) probe (b) N : P ratios in relation to microbial $\mathrm{N}: \mathrm{P}$ ratios. Each point represents a specific plot measured in 2009. Treatment abbreviations: $\mathrm{ct}$, ambient $\mathrm{CO}_{2}$ and temperature; $\mathrm{CT}$, ambient $\mathrm{CO}_{2}$ and $1.5 / 3^{\circ} \mathrm{C}$ day/night warming; $\mathrm{Ct}, 600$ ppmv $\mathrm{CO}_{2}$ and ambient temperature; $\mathrm{CT}, 600$ ppmv $\mathrm{CO}_{2}$ and $1.5 / 3^{\circ} \mathrm{C}$ day/ night warming.

the relatively wet year of 2009 and a strong negative relationship between mean early-season soil moisture content and plant $\mathrm{N}: \mathrm{P}$. A consistent increase in soil moisture with elevated $\mathrm{CO}_{2}$ and decrease with warming could therefore have important implications for the functioning of this ecosystem in the long term.

Reduced available N:P to both plants and microbes with increased moisture may have occurred through a greater proportional loss of $\mathrm{N}$ than $\mathrm{P}$, or a greater proportional supply of $\mathrm{P}$ than $\mathrm{N}$. Gaseous $\mathrm{N}$ loss through nitrification/denitrification or the loss of $\mathrm{NO}_{3}^{-}$through leaching could decrease the relative availability of $\mathrm{N}$, and thus simultaneously decrease the $\mathrm{N}: \mathrm{P}$ ratio of plants and microbes. Both gaseous $\mathrm{N}$ loss and leaching may increase in wetter conditions (Austin et al., 2004), contributing to the reduced N : P in plants and microbes observed with increased soil moisture (e.g. under elevated $\mathrm{CO}_{2}$ ). However, because $\mathrm{N}$ losses are small in these semiarid grasslands (Mosier et al., 2002; Burke et al., 2008), we expect that differential loss of $\mathrm{N}$ and $\mathrm{P}$ played a minor role in causing variable plant and microbial $\mathrm{N}$ : $\mathrm{P}$ ratios. Further, the increase in green plant $\mathrm{P}$ concentration and the green plant P pool (Fig. 2f,h) with increased soil moisture cannot be explained by increased $\mathrm{N}$ loss.
Changes in soil moisture caused by elevated $\mathrm{CO}_{2}$ or warming could also affect the proportional supply of $\mathrm{P}$ and N. Desorption and dissolution of inorganic $\mathrm{P}$ in the soil can function as an important source of $\mathrm{P}$ for plants and microbes, particularly in calcareous soils (Lajtha \& Bloomer, 1988; Tunesi et al., 1999). The desorption and dissolution of inorganic $\mathrm{P}$ depend on inorganic equilibria with the $\mathrm{P}$ concentration in soil solution. An increase in soil moisture increases the diffusivity of $\mathrm{P}$, thereby enhancing the uptake by plants and microbes (Lambers et al., 2006). Increased plant and microbial uptake of $\mathrm{P}$ would deplete soluble $\mathrm{P}$ rather rapidly if soluble $\mathrm{P}$ was not buffered by desorption and dissolution reactions (Fitter \& Hay, 2002). An increase in soil moisture may then have increased the supply of $\mathrm{P}$ to plants and microbes through enhanced desorption and dissolution. At our site, a large fraction of the total $\mathrm{P}$ pool in the soil was in inorganic form (Table 1), suggesting that $\mathrm{P}$ desorption and dissolution may be especially important for P supply in this system. Increased P desorption and dissolution with increased soil moisture could explain why both green plant $\mathrm{P}$ concentrations and pools increased with increased soil moisture (Fig. 2f,h). However, the decrease in green plant $\mathrm{N}$ concentration with increased soil moisture (Fig. 2e) was most probably a result of a dilution effect caused by the increase in plant productivity, as the green plant $\mathrm{N}$ pool was unaffected by soil moisture (Fig. 2g). This also suggests that the decrease in available $\mathrm{N}$ with increased soil moisture (Fig. 2c) was caused by an increase in microbial $\mathrm{N}$ immobilization, as opposed to an increase in plant uptake. Previously, we have shown that irrigation and elevated $\mathrm{CO}_{2}$-induced increases in soil moisture also increase microbial $\mathrm{N}$ immobilization (Dijkstra et al., 2010; Carrillo et al., 2012). Here, we propose that the soil moisture-induced increases in microbial $\mathrm{N}$ immobilization may also have been stimulated by increased microbial P supply through desorption and dissolution.

Further indirect support for the importance of inorganic reactions in controlling $\mathrm{P}$ supply at our site comes from the relationship between microbial and plant $\mathrm{N}$ : $\mathrm{P}$. If plant $\mathrm{N}$ and $\mathrm{P}$ were predominantly supplied through organic matter decomposition, ecological stoichiometry theory would predict that the relationship between plant and microbial N : P ratios should be negative (Sterner \& Elser, 2002). When microbes depend solely on soil organic matter as their source of $\mathrm{N}$ and $\mathrm{P}$, a shift to greater uptake and storage of $\mathrm{N}$ relative to $\mathrm{P}$ during soil organic matter decomposition should result in greater release of $\mathrm{P}$ relative to $\mathrm{N}$. In contrast, available and plant $\mathrm{N}: \mathrm{P}$ ratios were both positively related to microbial N:P ratios in the soil (Fig. 3). This suggests that the availability of $\mathrm{P}$ was not primarily controlled by soil organic matter decomposition. It also suggests a decoupling of the supply of $\mathrm{N}$ (released mostly through mineralization) and P (mostly through desorption/dissolution) in this system. Similarly, decoupling of N and $\mathrm{P}$ supply from organic matter may also occur because $\mathrm{N}$ is released through biological mineralization (or oxidation of organic matter), whereas $\mathrm{P}$ can also be released through biochemical mineralization (release from $P$ esters with the help of extracellular enzymes; McGill \& Cole, 1981).

Under dry conditions, when geochemical reactions of $\mathrm{P}$ are limited by $\mathrm{P}$ diffusivity, the warming effect on $\mathrm{N}$ and $\mathrm{P}$ availability may have been largely driven by changes in soil organic matter 
(a)

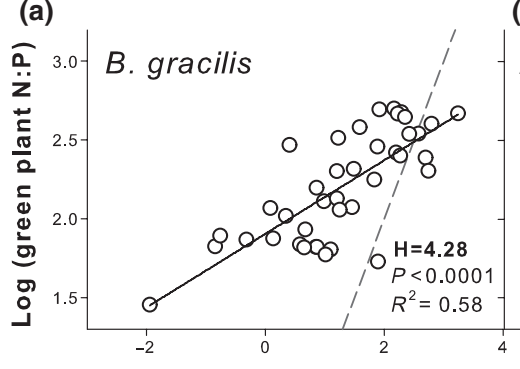

(b)

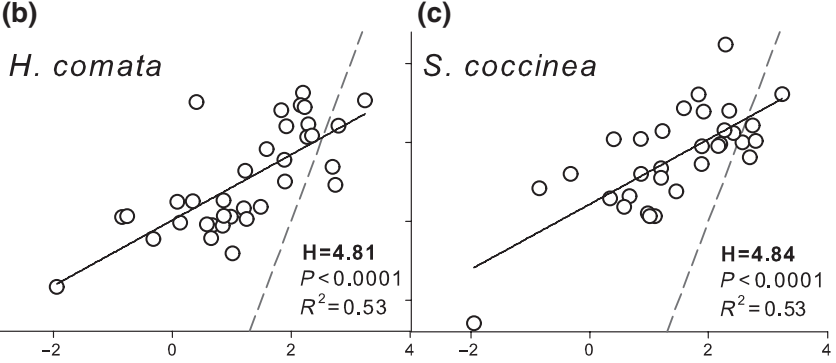

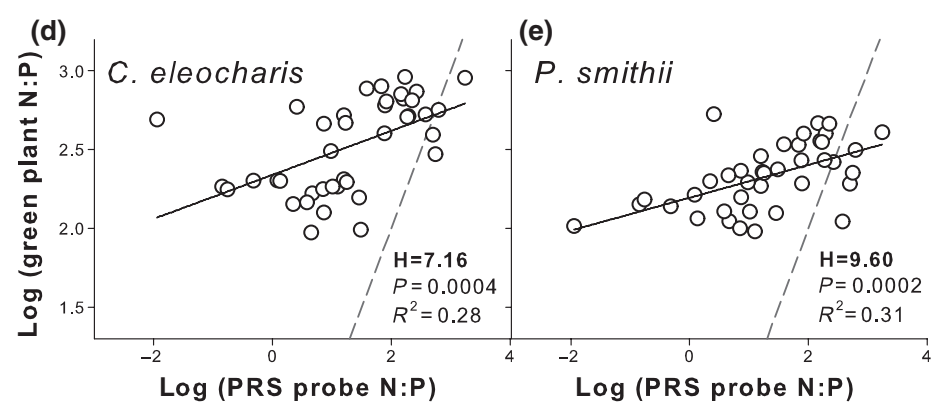

Fig. 4 Relationship between N : P ratios in green plant tissue of five dominant grasses and N : P ratios on Plant Root Simulator (PRS) probes. Relationships are shown for the C4 grass Bouteloua gracilis (a), the C3 grass Hesperostipa comata (b), the forb Sphaeralcea coccinea (c), the sedge Carex eleocharis (d) and the C3 grass Pascopyrum smithii (e). Each point represents the N : P ratios measured in a specific plot for a specific year (2007 and 2009). For each species, the $\mathrm{H}$ factor is reported, which quantifies the degree of stoichiometric flexibility or homeostasis: a larger $\mathrm{H}$ (slope of the regression deviating more strongly from the dashed $1: 1$ line) indicates a smaller degree of flexibility or greater degree of homeostasis (see the Materials and Methods section for details).

decomposition. For instance, available P measured with the PRS probes increased with warming in the relatively dry year of 2007 (Table S4), despite a potentially lower P supply from geochemical reactions as a result of warming-induced soil drying. This suggests that warming increased P mineralization in that year. Available $\mathrm{N}$ and plant $\mathrm{N}$ pools also increased with warming, further suggesting enhanced $\mathrm{N}$ mineralization with warming (Dijkstra et al., 2010). In contrast, the green plant $\mathrm{P}$ pool was not affected by warming in 2007 (Table S3), possibly because, under dry soil conditions, plant uptake of $\mathrm{P}$ was limited by the diffusion of $\mathrm{P}$ to the root, more so than N (Fitter \& Hay, 2002). A direct warming effect on P mineralization may also help to explain why the available $\mathrm{P}$ did not relate to soil moisture (Fig. 2d). Overall, the supply of $\mathrm{P}$ at our site is likely to be controlled by a suite of mechanisms that are active under different environmental conditions, because of the nearly co-dominant inorganic and organic $\mathrm{P}$ sources.

We have no direct evidence for $\mathrm{N}$ and $\mathrm{P}$ limitation at our site. However, there are several reasons why we believe that both $\mathrm{N}$ and $\mathrm{P}$ were important for plant growth at our study site. First, soil available $\mathrm{N}$ and $\mathrm{P}$ concentrations at our site were low, increasing the likelihood that both nutrients affected plant growth (Harpole et al., 2011). The low $\mathrm{N}$ and $\mathrm{P}$ conditions are illustrated by the extremely low losses of $\mathrm{N}$ as $\mathrm{N}_{2} \mathrm{O}$ at this site $\left(<2 \mathrm{mg} \mathrm{N} \mathrm{m}^{-2} \mathrm{yr}^{-1}\right.$, F. A. Dijkstra et al., unpublished results) and the low levels of available $\mathrm{P}$ (4-7 $\mathrm{mg} \mathrm{P} \mathrm{kg}^{-1}$ soil, measured in nonfumigated soil extracts) relative to those in 98 North American grassland soils (2$100 \mathrm{mg} \mathrm{Pg}^{-1}$ soil; Craine \& Jackson, 2010). Second, speciesweighted green plant $\mathrm{N}: \mathrm{P}$ ratios in 2007 and 2008 were between 10 and 20, and, although critical plant N : P ratios for nutrient limitation are not always unambiguous, values between 10 and 20 may indicate limitation of both $\mathrm{N}$ and $\mathrm{P}$ for plant growth at the ecosystem level (Güsewell, 2004). In the relatively wet year 2009 , when green plant $\mathrm{N}: \mathrm{P}$ ratios were often below 10 , plant growth may have become more $\mathrm{N}$ limited. Third, we found indirect evidence that $\mathrm{N}$ made available to plants through microbial mineralization may be mediated by $\mathrm{P}$ supply to microbes that have a relatively high $\mathrm{P}$ requirement. Indeed, the dependence of plant productivity on both $\mathrm{N}$ and $\mathrm{P}$ may be widespread in grasslands because of the nature of the interaction between $\mathrm{P}$ and $\mathrm{N}$ availability (Craine \& Jackson, 2010).

Although the aboveground biomass of $\mathrm{C} 3$ and $\mathrm{C} 4$ grasses responded differently to elevated $\mathrm{CO}_{2}$ and warming (Morgan et al., 2011) and the N : P ratio differed among plant species (Table S1), elevated $\mathrm{CO}_{2}$ and warming effects on overall plant $\mathrm{N}: \mathrm{P}$ ratios were most probably not caused by differential species responses and shifts in vegetation. The $\mathrm{N}: \mathrm{P}$ ratios of the three dominant plant species B. gracilis, H. comata, and P. smithii all showed similar responses to elevated $\mathrm{CO}_{2}$ and warming. In contrast, the $\mathrm{N}: \mathrm{P}$ ratios of C. eleocharis and S. coccinea did not respond to elevated $\mathrm{CO}_{2}$ and warming, but their contribution to the total aboveground biomass was relatively small (on average $10 \%$ for C. eleocharis and $3 \%$ for S. coccinea). All plant biomass samples were taken at peak biomass in mid-July, when plants were at a similar late stage of development, indicating that potential differences in plant $\mathrm{N}: \mathrm{P}$ among species and years caused by developmental differences were most probably small.

The biomass N:P ratios of individual plant species were positively related to soil-available $\mathrm{N}: \mathrm{P}$ ratios (none were strongly homeostatic), but species varied in their stoichiometric flexibility in response to changes in soil-available N:P (Fig. 4). It has been suggested that environments with a temporally variable nutrient supply may favour species that are flexible in their $\mathrm{N}: \mathrm{P}$ 
stoichiometry (Sardans etal., 2012), as the maintenance of stoichiometric homeostasis under these conditions is energetically expensive for plants (Sterner \& Elser, 2002). In semiarid grasslands, flexible or nonhomeostatic nutrient uptake rates may also be advantageous for plants, so that $\mathrm{N}$ uptake is not impeded by low $\mathrm{P}$ availability during the long dry periods, and vice versa, and so that $P$ uptake is not hindered by the relatively low $\mathrm{N}$ availability during the short wet periods. We found partial support for this. Warming induced more extreme soil moisture conditions (i.e. faster and more severe soil drying after rainfall events) and increased the aboveground biomass of B. gracilis (Morgan et al., 2011), which also showed the greatest flexibility in N:P. Similarly, water savings under elevated $\mathrm{CO}_{2}$ reduced the extremes in soil moisture at our site, which could be relatively more advantageous to species with low N : P flexibility. Indeed, P. smithii showed the lowest N : P flexibility and was one of the $\mathrm{C} 3$ grasses that responded most strongly to elevated $\mathrm{CO}_{2}$ in 2007 and 2008. In contrast, H. comata and S. coccinea, which showed a similar high flexibility in $\mathrm{N}: \mathrm{P}$ to B. gracilis, did not respond to warming or elevated $\mathrm{CO}_{2}$. Possibly, differences in photosynthetic pathways and rooting depths (LeCain etal. 2006) confound the clear relationships between speciesspecific N:P flexibility and their responses to climate change. Stoichiometric homeostasis has also been linked to plant dominance in a similar semiarid grassland in Inner Mongolia (Yu et al., 2010), but we found no strong support for this. At our site, $B$. gracilis and $P$. smithii were two of the three dominant species, but showed the most and least $\mathrm{N}$ : P flexibility, respectively.

It has been argued that plant productivity may become increasingly constrained by $\mathrm{N}$ under elevated $\mathrm{CO}_{2}$ alone (Luo et al., 2004; Norby et al., 2010). Our results suggest that an increase in $\mathrm{P}$ availability relative to $\mathrm{N}$ under elevated $\mathrm{CO}_{2}$ may further exacerbate $\mathrm{N}$ constraints. However, warming could alleviate $\mathrm{N}$ constraints on plant growth under elevated $\mathrm{CO}_{2}$, and may increase $\mathrm{P}$ constraints, particularly under dry conditions. As soils dried out more rapidly with warming, $\mathrm{P}$ became progressively less available to plants relative to N. It is unclear whether similar effects would occur in wetter environments and in noncalcareous soils that contain less inorganic $\mathrm{P}$, and where $\mathrm{P}$ supply is largely controlled by organic matter decomposition. Enhanced precipitation increased plant $\mathrm{P}$ uptake, but elevated $\mathrm{CO}_{2}$ and warming had no effect on plant $\mathrm{P}$ or $\mathrm{N}: \mathrm{P}$ in an annual grassland in California (Menge \& Field, 2007) or in other mesic ecosystems (Chapin et al., 1995; Niklaus et al., 1998; Finzi etal., 2001). Our results suggest that primary productivity and microbial activity in semiarid grasslands that occur widely on calcareous soils may become more reliant on $\mathrm{P}$ availability in a warmer and drier world. The enormous increase in anthropogenic $\mathrm{N}$ fixation and resultant increase in atmospheric $\mathrm{N}$ deposition (Galloway et al., 2008) could further exacerbate the increased $\mathrm{P}$ constraints on plant growth in a warmer and drier environment. Thus, the dynamics of $\mathrm{P}$ relative to $\mathrm{N}$ will be critical in predicting responses of semiarid grasslands to climate change.

\section{Acknowledgements}

We thank D. Smith for the installation and operation of the PHACE experiment, E. Hardy for assistance in installation,
M. Parsons for assistance with data collection, F. Miglietta for advice and help on the installation of the FACE system, B. Kimball for advice and help on the installation of the infrared heating system, and R. Phillips and three anonymous reviewers for comments on the manuscript. Research was supported by the US Department of Agriculture (USDA)-Agricultural Research Service Climate Change, Soils \& Emissions Program, the US National Science Foundation (NSF) (DEB\# 1021559), and the US Department of Energy's Office of Science (Biological and Environmental Research). F.A.D. was supported by a fellowship from the Australian Research Council (FT100100779). The mention of commercial products is solely for the purpose of providing specific information and does not imply the recommendation or endorsement by the USDA. Any opinions, findings, and conclusions or recommendations expressed in this material are those of the authors and do not necessarily reflect the views of the US NSF.

\section{References}

Achat DL, Bakker MR, Morel C. 2009. Process-based assessment of phosphorus availability in a low phosphorus sorbing forest soil using isotopic dilution methods. Soil Science Society of America Journal 73: 2131-2142.

An Y, Wan S, Zhou X, Subedar AA, Wallace LL, Luo Y. 2005. Plant nitrogen concentration, use efficiency, and contents in a tallgrass prairie ecosystem under experimental warming. Global Change Biology 11: 1733-1744.

Austin AT, Yahdjian L, Stark JM, Belnap J, Porporato A, Norton U, Ravetta DA, Schaeffer SM. 2004. Water pulses and biogeochemical cycles in arid and semiarid ecosystems. Oecologia 141: 221-235.

Brookes PC, Landman A, Pruden G, Jenkinson DS. 1985. Chloroform fumigation and the release of soil nitrogen: a rapid direct extraction method to measure microbial biomass nitrogen in soil. Soil Biology and Biochemistry 17: 837-842.

Brookes PC, Powlson DS, Jenkinson DS. 1982. Measurement of microbial biomass phosphorus in soil. Soil Biology and Biochemistry 14: 319-329.

Burke IC, Mosier AR, Hook PB, Milchunas DG, Barrett JE, Vinton MA, McCulley RL, Kaye JP, Gill RA, Epstein HE et al. 2008. Soil organic matter and nutrient dynamics of shortgrass steppe ecosystems. In: Lauenroth WK, Burke IC, eds. Ecology of the shortgrass steppe. A long-term perspective. Oxford, UK: Oxford University Press, 306-341.

Carrillo Y, Dijkstra FA, Pendall E, Morgan JA, Blumenthal DM. 2012. Controls over soil nitrogen pools in a semiarid grassland under elevated $\mathrm{CO}_{2}$ and warming. Ecosystems 15: 761-774.

Chapin FS III, Shaver GR, Giblin AE, Nadelhoffer KJ, Laundre JA. 1995. Responses of arctic tundra to experimental and observed changes in climate. Ecology 76: 694-711.

Cleveland CC, Liptzin D. 2007. C : N : P stoichiometry in soil: is there a "Redfield ratio" for the microbial biomass? Biogeochemistry 85: 235-252.

Craine JM, Jackson RD. 2010. Plant nitrogen and phosphorus limitation in 98 North American grassland soils. Plant and Soil 334: 73-84.

Craine JM, Morrow C, Stock WD. 2008. Nutrient concentration ratios and colimitation in South African grasslands. New Phytologist 179: 829-836.

Dijkstra FA, Blumenthal D, Morgan JA, Pendall E, Carrillo Y, Follett RF. 2010. Contrasting effects of elevated $\mathrm{CO}_{2}$ and warming on nitrogen cycling in a semiarid grassland. New Phytologist 187: 426-437.

Elser JJ, Bracken MES, Cleland EE, Gruner DS, Harpole WS, Hillebrand H, Ngai JT, Seabloom EW, Shurin JB, Smith JE. 2007. Global analysis of nitrogen and phosphorus limitation of primary producers in freshwater, marine and terrestrial ecosystems. Ecology Letters 10: 1135-1142.

Finzi AC, Allen AS, DeLucia EH, Ellsworth DS, Schlesinger WH. 2001. Forest litter production, chemistry, and decomposition following two years of free-air $\mathrm{CO}_{2}$ enrichment. Ecology 82: 470-484.

Fitter AH, Hay RKM. 2002. Environmental physiology of plants, 3rd edn. San Diego, CA, USA: Academic Press. 
Galloway JN, Townsend AR, Erisman JW, Bekunda M, Cai Z, Freney JR, Martinelli LA, Seitzinger SP, Sutton MA. 2008. Transformation of the nitrogen cycle: recent trends, questions, and potential solutions. Science 320: 889-892.

Güsewell S. 2004. N : P ratios in terrestrial plants: variation and functional significance. New Phytologist 164: 243-266.

Güsewell S, Gessner MO. 2009. N : P ratios influence litter decomposition and colonization by fungi and bacteria in microcosms. Functional Ecology 23: 211-219.

Harpole WS, Ngai JT, Cleland EE, Seabloom EW, Borer ET, Bracken MES, Elser JJ, Gruner DS, Hillebrand H, Shurin JB et al. 2011. Nutrient co-limitation of primary producer communities. Ecology Letters 14: 852-862.

Heimann M, Reichstein M. 2008. Terrestrial ecosystem carbon dynamics and climate feedbacks. Nature 451: 289-292.

Hofmockel KS, Fierer N, Colman BP, Jackson RB. 2010. Amino acid abundance and proteolytic potential in North American soils. Oecologia 163: 1069-1078.

Hovenden MJ, Newton PCD, Carran RA, Theobald P, Wills KE, Vander Schoor JK, Williams AL, Osanai Y. 2008. Warming prevents the elevated $\mathrm{CO}_{2}$-induced reduction in available soil nitrogen in a temperate, perennial grassland. Global Change Biology 14: 1018-1024.

Jackson ML. 1958. Soil chemical analysis. Englewood Cliffs, NJ, USA: PrenticeHall, Inc.

Johnson DW, Dijkstra FA, Cheng W. 2007. The effects of Glycine max and Helianthus annuus on nutrient availability in two soils. Soil Biology and Biochemistry 39: 2160-2163.

Lajtha K, Bloomer SH. 1988. Factors affecting phosphate sorption and phosphate retention in a desert ecosystem. Soil Science 146: 160-167.

Lambers H, Shane MW, Cramer MD, Pearse SJ, Veneklaas EJ. 2006. Root structure and functioning for efficient acquisition of phosphorus: matching morphological and physiological traits. Annals of Botany 98: 693-713.

LeCain DR, Morgan JA, Milchunas DG, Mosier AR, Nelson JA, Smith DP. 2006. Root biomass of individual species, and root size characteristics after five years of $\mathrm{CO}_{2}$ enrichment on native shortgrass steppe. Plant and Soil 279: 219-228.

Liu Z, Fu B, Zheng X, Liu G. 2010. Plant biomass, soil water content and soil N:P ratio regulating soil microbial functional diversity in a temperate steppe: a regional scale study. Soil Biology and Biochemistry 42: 445-450.

Luo Y, Su B, Currie WS, Dukes JS, Finzi A, Hartwig U, Hungate B, McMurtrie RE, Oren R, Parton WJ et al. 2004. Progressive nitrogen limitation of ecosystem responses to rising atmospheric carbon dioxide. BioScience 54: 731-739.

Macklon AES, Mackie-Dawson LA, Sim A, Shand CA, Lilly A. 1994. Soil P resources, plant growth and rooting characteristics in nutrient poor upland grasslands. Plant and Soil 163: 257-266.

McGill WB, Cole CV. 1981. Comparative aspects of cycling of organic C, N, S, and P through soil organic matter. Geoderma 26: 267-286.

Melillo JM, Steudler PA, Aber JD, Newkirk K, Lux H, Bowles FP, Catricala C, Magill A, Ahrens T, Morrisseau S. 2002. Soil warming and carbon-cycle feedbacks to the climate system. Science 298: 2173-2176.

Menge DNL, Field CB. 2007. Simulated global changes alter phosphorus demand in annual grassland. Global Change Biology 13: 2582-2591.

Morgan JA, Lecain DR, Pendall E, Blumenthal DM, Kimball BA, Carrillo Y, Williams DG, Heisler-White J, Dijkstra FA, West M. 2011. C 4 grasses prosper as carbon dioxide eliminates desiccation in warmed semi-arid grassland. Nature 476: 202-205.

Mosier AR, Morgan JA, King JY, LeCain D, Milchunas DG. 2002. Soilatmosphere exchange of $\mathrm{CH}_{4}, \mathrm{CO}_{2}, \mathrm{NO}_{\mathrm{x}}$, and $\mathrm{N}_{2} \mathrm{O}$ in the Colorado shortgrass steppe under elevated $\mathrm{CO}_{2}$. Plant and Soil 240: 201-211.

Näsholm T, Kielland K, Ganeteg U. 2009. Uptake of organic nitrogen by plants. New Phytologist 182: 31-48.

Niklaus PA, Leadley PW, Stöcklin J, Körner C. 1998. Nutrient relations in calcareous grassland under elevated $\mathrm{CO}_{2}$. Oecologia 116: 67-75.

Niu S, Sherry RA, Zhou X, Wan S, Luo Y. 2010. Nitrogen regulation of the climate-carbon feedback: evidence from a long-term global change experiment. Ecology 91: 3261-3273.

Norby RJ, Warren JM, Iversen CM, Medlyn BE, McMurtrie RE. 2010. $\mathrm{CO}_{2}$ enhancement of forest productivity constrained by limited nitrogen availability. Proceedings of the National Academy of Sciences, USA 107: 19368-19373.
Olsen SR, Sommers LE 1982. Phosphorus. In: Pace AL, Miller RH, Keeney DR, eds. Methods of soil analysis. Part 2. Chemical and microbiological properties. Madison, WI, USA: American Society of Agronomy, Inc., 403-430.

Reich PB. 2009. Elevated $\mathrm{CO}_{2}$ reduces losses of plant diversity caused by nitrogen deposition. Science 326: 1399-1402.

Rustad L, Campbell J, Marion G, Norby R, Mitchell M, Hartley A, Cornelissen J, Gurevitch J, GCTE-NEWS. 2001. A meta-analysis of the response of soil respiration, net nitrogen mineralization, and aboveground plant growth to experimental ecosystem warming. Oecologia 126: 543-562.

Sardans J, Rivas-Ubach A, Penuelas J. 2012. The C : N : P stoichiometry of organisms and ecosystems in a changing world: a review and perspectives. Perspectives in Plant Ecology, Evolution and Systematics 14: 33-47.

Saunders WMH, Williams EG. 1955. Observations on the determination of total organic phosphorus in soils. Journal of Soil Science 6: 254-267.

Sherrod LA, Dunn G, Peterson GA, Kolberg RL. 2002. Inorganic carbon analysis by modified pressure-calcimeter method. Soil Science Society of America Journal 66: 299-305.

Sterner RW, Elser JJ. 2002 Ecological stoichiometry. The biology of elements from molecules to the biosphere. Princeton, NJ, USA: Princeton University Press.

Tunesi S, Poggi V, Gessa C. 1999. Phosphate adsorption and precipitation in calcareous soils: the role of calcium ions in solution and carbonate minerals. Nutrient Cycling in Agroecosystems 53: 219-227.

Vitousek PM, Farrington H. 1997. Nutrient limitation and soil development: experimental test of a biogeochemical theory. Biogeochemistry 37: 63-75.

Vitousek PM, Howarth RW. 1991. Nitrogen limitation on land and in the sea: how can it occur? Biogeochemistry 13: 87-115.

Walker TW, Syers JK. 1976. The fate of phosphorus during pedogenesis. Geoderma 15: 1-19.

Wassen MJ, Venterink HO, Lapshina ED, Tanneberger F. 2005. Endangered plants persist under phosphorus limitation. Nature 437: 547-550.

Yang X, Post WM. 2011. Phosphorus transformations as a function of pedogenesis: a synthesis of soil phosphorus data using Hedley fractionation method. Biogeosciences 8: 2907-2916.

Yu Q, Chen Q, Elser JJ, He N, Wu H, Zhang G, Wu J, Bai Y, Han X. 2010. Linking stoichiometric homoeostasis with ecosystem structure, functioning and stability. Ecology Letters 13: 1390-1399.

\section{Supporting Information}

Additional Supporting Information may be found in the online version of this article.

Table S1 Average green plant N : P ratios by species

Table S2 Average green and senesced plant $\mathrm{N}$ and P concentrations (\%) averaged across all five species

Table S3 Average N and P pools in green plant biomass of the five species combined

Table S4 Average N and P pools on Plant Root Simulator (PRS) probes (2007 and 2009) and N:C, P:C and N and P pools in microbial biomass (2009)

Please note: Wiley-Blackwell are not responsible for the content or functionality of any supporting information supplied by the authors. Any queries (other than missing material) should be directed to the New Phytologist Central Office. 
Climate change alters stoichiometry of phosphorus and nitrogen in a semiarid grassland

Feike A. Dijkstra, Elise Pendall, Jack A. Morgan, Dana M. Blumenthal, Yolima Carrillo, Daniel R. LeCain, Ronald F. Follett, David G. Williams

Table S1 Average green plant N:P ratios by species

Table S2 Average green and senesced plant N and P concentrations (\%) averaged across all five species

Table S3 Average N and P pools in green plant biomass of the five species combined Table S4 Average N and P pools on PRS-probes (2007 and 2009) and N:C, P:C and N and P pools in microbial biomass (2009) 
Table S1 Average green plant N:P ratios by species

\begin{tabular}{|c|c|c|c|c|c|c|}
\hline \multirow[t]{3}{*}{ Treatment } & \multicolumn{6}{|l|}{ Species } \\
\hline & \multicolumn{3}{|c|}{ B. gracilis $\mathrm{N}: \mathrm{P}$} & \multicolumn{3}{|c|}{ C. eleocharis $\mathrm{N}: \mathrm{P}$} \\
\hline & 2007 & 2008 & 2009 & 2007 & 2008 & 2009 \\
\hline ct & $13.3 \pm 0.6$ & $12.6 \pm 0.7$ & $6.8 \pm 0.4$ & $16.9 \pm 0.7$ & $16.1 \pm 0.7$ & $8.5 \pm 0.5$ \\
\hline cT & $14.2 \pm 0.4$ & $15.3 \pm 0.7$ & $9.2 \pm 0.8$ & $17.0 \pm 0.7$ & $16.8 \pm 0.7$ & $10.5 \pm 1.5$ \\
\hline $\mathrm{Ct}$ & $10.3 \pm 1.3$ & $10.9 \pm 0.8$ & $6.3 \pm 0.1$ & $15.5 \pm 0.7$ & $15.6 \pm 0.4$ & $9.7 \pm 0.1$ \\
\hline CT & $10.2 \pm 0.7$ & $11.8 \pm 0.9$ & $6.5 \pm 0.8$ & $14.0 \pm 1.2$ & $15.7 \pm 1.7$ & $11.5 \pm 1.3$ \\
\hline$c t-i$ & $11.1 \pm 0.5$ & $11.1 \pm 0.7$ & $6.8 \pm 0.4$ & $12.0 \pm 0.6$ & $15.9 \pm 0.9$ & $10.9 \pm 0.4$ \\
\hline \multicolumn{7}{|c|}{ ANOVA P-values } \\
\hline $\mathrm{CO}_{2}$ & 0.0006 & 0.004 & 0.01 & 0.02 & 0.44 & 0.28 \\
\hline Temp & 0.63 & 0.04 & 0.03 & 0.40 & 0.74 & 0.08 \\
\hline $\mathrm{CO}_{2} \times$ Temp & 0.54 & 0.28 & 0.08 & 0.34 & 0.74 & 0.93 \\
\hline Irrigation & 0.02 & 0.15 & 0.98 & 0.0009 & 0.86 & 0.005 \\
\hline \multirow[t]{3}{*}{ Treatment } & \multicolumn{6}{|l|}{ Species } \\
\hline & \multicolumn{3}{|c|}{ H. comata $\mathrm{N}: \mathrm{P}$} & \multicolumn{3}{|c|}{ P. smithii N:P } \\
\hline & 2007 & 2008 & 2009 & 2007 & 2008 & 2009 \\
\hline $\mathrm{ct}$ & $14.8 \pm 0.7$ & $11.1 \pm 0.6$ & $7.6 \pm 0.3$ & $12.5 \pm 0.4$ & $12.5 \pm 0.3$ & $9.3 \pm 0.4$ \\
\hline cT & $14.4 \pm 0.8$ & $15.5 \pm 0.8$ & $9.8 \pm 2.0$ & $12.7 \pm 1.3$ & $16.3 \pm 2.1$ & $11.3 \pm 1.2$ \\
\hline $\mathrm{Ct}$ & $11.2 \pm 0.7$ & $10.3 \pm 0.5$ & $7.2 \pm 0.2$ & $11.0 \pm 0.5$ & $11.3 \pm 0.5$ & $7.9 \pm 0.3$ \\
\hline $\mathrm{CT}$ & $10.5 \pm 1.2$ & $9.4 \pm 0.8$ & $6.8 \pm 0.6$ & $10.7 \pm 0.5$ & $11.7 \pm 0.9$ & $8.6 \pm 0.7$ \\
\hline$c t-i$ & $11.1 \pm 0.8$ & $10.3 \pm 0.6$ & $7.2 \pm 0.5$ & $12.0 \pm 0.9$ & $11.5 \pm 0.9$ & $9.3 \pm 0.8$ \\
\hline \multicolumn{7}{|c|}{ ANOVA P-values } \\
\hline $\mathrm{CO}_{2}$ & 0.002 & 0.0002 & 0.09 & 0.03 & 0.03 & 0.009 \\
\hline Temp & 0.58 & 0.02 & 0.35 & 0.95 & 0.09 & 0.08 \\
\hline $\mathrm{CO}_{2} \times$ Temp & 0.88 & 0.002 & 0.21 & 0.74 & 0.18 & 0.38 \\
\hline Irrigation & 0.01 & 0.38 & 0.48 & 0.61 & 0.31 & 0.93 \\
\hline \multirow[t]{3}{*}{ Treatment } & \multicolumn{6}{|l|}{ Species } \\
\hline & \multicolumn{3}{|c|}{ S. coccinea $\mathrm{N}: \mathrm{P}$} & & & \\
\hline & 2007 & 2008 & 2009 & & & \\
\hline $\mathrm{ct}$ & $12.4 \pm 0.3$ & $11.9 \pm 0.9$ & $8.9 \pm 0.6$ & & & \\
\hline cT & $14.1 \pm 0.9$ & $14.9 \pm 0.8$ & $10.4 \pm 1.1$ & & & \\
\hline $\mathrm{Ct}$ & $12.2 \pm 0.9$ & $12.3 \pm 0.9$ & $8.9 \pm 0.7$ & & & \\
\hline CT & $12.4 \pm 1.4$ & $12.9 \pm 1.6$ & $8.1 \pm 1.8$ & & & \\
\hline$c t-i$ & $12.5 \pm 0.5$ & $13.2 \pm 0.4$ & $10.8 \pm 0.2$ & & & \\
\hline \multicolumn{7}{|c|}{ ANOVA P-values } \\
\hline $\mathrm{CO}_{2}$ & 0.42 & 0.50 & 0.43 & & & \\
\hline Temp & 0.42 & 0.15 & 0.78 & & & \\
\hline $\mathrm{CO}_{2} \times$ Temp & 0.52 & 0.31 & 0.41 & & & \\
\hline Irrigation & 0.32 & 0.23 & 0.01 & & & \\
\hline
\end{tabular}

ct: Ambient $\mathrm{CO}_{2}$, ambient temperature; $\mathrm{cT}$ : ambient $\mathrm{CO}_{2}$, elevated temperature; $\mathrm{Ct}$ : elevated $\mathrm{CO}_{2}$, ambient temperature; $\mathrm{CT}$ : elevated $\mathrm{CO}_{2}$, elevated temperature; $\mathrm{ct}$-i: ambient $\mathrm{CO}_{2}$, ambient temperature, irrigated. 
Table S2 Average green and senesced plant $\mathrm{N}$ and $\mathrm{P}$ concentrations (\%) averaged across all five species

\begin{tabular}{|c|c|c|c|c|c|c|}
\hline \multirow[t]{3}{*}{ Treatment } & \multirow{2}{*}{\multicolumn{3}{|c|}{$\begin{array}{l}\text { Green plant } \\
\mathrm{N} \text { concentration (\%) }\end{array}$}} & \multirow{2}{*}{\multicolumn{3}{|c|}{$\begin{array}{l}\text { Green plant } \\
\text { P concentration (\%) }\end{array}$}} \\
\hline & & & & & & \\
\hline & 2007 & 2008 & 2009 & 2007 & 2008 & 2009 \\
\hline $\mathrm{ct}$ & $1.39 \pm 0.02$ & $1.37 \pm 0.04$ & $0.96 \pm 0.03$ & $0.106 \pm 0.003$ & $0.107 \pm 0.004$ & $0.124 \pm 0.008$ \\
\hline cT & $1.45 \pm 0.03$ & $1.61 \pm 0.05$ & $1.02 \pm 0.07$ & $0.111 \pm 0.012$ & $0.107 \pm 0.006$ & $0.106 \pm 0.005$ \\
\hline $\mathrm{Ct}$ & $1.16 \pm 0.01$ & $1.08 \pm 0.03$ & $1.00 \pm 0.02$ & $0.101 \pm 0.006$ & $0.097 \pm 0.003$ & $0.139 \pm 0.007$ \\
\hline CT & $1.16 \pm 0.02$ & $1.24 \pm 0.06$ & $0.95 \pm 0.04$ & $0.109 \pm 0.008$ & $0.110 \pm 0.009$ & $0.119 \pm 0.011$ \\
\hline$c t-i$ & $1.41 \pm 0.06$ & $1.39 \pm 0.05$ & $1.07 \pm 0.02$ & $0.123 \pm 0.005$ & $0.122 \pm 0.006$ & $0.137 \pm 0.006$ \\
\hline \multicolumn{7}{|c|}{ ANOVA P-values } \\
\hline $\mathrm{CO}_{2}$ & $<0.0001$ & $<0.0001$ & 0.46 & 0.73 & 0.54 & 0.09 \\
\hline Temp & 0.16 & 0.0009 & 0.91 & 0.41 & 0.31 & 0.02 \\
\hline $\mathrm{CO}_{2} \times$ Temp & 0.11 & 0.53 & 0.2 & 0.85 & 0.29 & 0.85 \\
\hline Irrigation & 0.76 & 0.75 & 0.02 & 0.02 & 0.07 & 0.24 \\
\hline \multirow[t]{2}{*}{ Treatment } & \multicolumn{3}{|c|}{$\begin{array}{l}\text { Senesced plant } \\
\mathrm{N} \text { concentration (\%) }\end{array}$} & \multicolumn{3}{|c|}{$\begin{array}{l}\text { Senesced plant } \\
\text { P concentration (\%) }\end{array}$} \\
\hline & 2007 & 2008 & 2009 & 2007 & 2008 & 2009 \\
\hline $\mathrm{ct}$ & $0.85 \pm 0.03$ & $0.79 \pm 0.03$ & $0.82 \pm 0.03$ & $0.049 \pm 0.002$ & $0.043 \pm 0.004$ & $0.058 \pm 0.004$ \\
\hline cT & $0.87 \pm 0.04$ & $0.87 \pm 0.04$ & $0.88 \pm 0.04$ & $0.048 \pm 0.006$ & $0.046 \pm 0.002$ & $0.053 \pm 0.003$ \\
\hline $\mathrm{Ct}$ & $0.73 \pm 0.02$ & $0.70 \pm 0.03$ & $0.80 \pm 0.01$ & $0.041 \pm 0.002$ & $0.046 \pm 0.003$ & $0.067 \pm 0.002$ \\
\hline CT & $0.69 \pm 0.04$ & $0.76 \pm 0.03$ & $0.76 \pm 0.04$ & $0.045 \pm 0.006$ & $0.053 \pm 0.006$ & $0.060 \pm 0.007$ \\
\hline ct-i & $0.91 \pm 0.04$ & $0.78 \pm 0.04$ & $0.82 \pm 0.03$ & $0.056 \pm 0.006$ & $0.051 \pm 0.004$ & $0.067 \pm 0.004$ \\
\hline \multicolumn{7}{|c|}{ ANOVA P-values } \\
\hline $\mathrm{CO}_{2}$ & 0.0004 & 0.006 & 0.05 & 0.18 & 0.26 & 0.08 \\
\hline Temp & 0.73 & 0.03 & 0.79 & 0.72 & 0.25 & 0.21 \\
\hline $\mathrm{CO}_{2} \times \mathrm{Temp}$ & 0.31 & 0.76 & 0.15 & 0.58 & 0.60 & 0.82 \\
\hline Irrigation & 0.27 & 0.88 & 0.98 & 0.33 & 0.18 & 0.13 \\
\hline
\end{tabular}

ct: Ambient $\mathrm{CO}_{2}$, ambient temperature; $\mathrm{cT}$ : ambient $\mathrm{CO}_{2}$, elevated temperature; $\mathrm{Ct}$ : elevated $\mathrm{CO}_{2}$, ambient temperature; $\mathrm{CT}$ : elevated $\mathrm{CO}_{2}$, elevated temperature; ct-i: ambient $\mathrm{CO}_{2}$, ambient temperature, irrigated. 
Table S3 Average $\mathrm{N}$ and $\mathrm{P}$ pools in green plant biomass of the five species combined

\begin{tabular}{|c|c|c|c|c|c|c|}
\hline Treatment & \multicolumn{3}{|l|}{$\begin{array}{l}\text { Green } \\
\text { plant } \mathrm{N} \\
\left(\mathrm{mg} \mathrm{m}^{-2}\right)\end{array}$} & \multicolumn{3}{|l|}{$\begin{array}{l}\text { Green } \\
\text { plant P } \\
\left(\mathrm{mg} \mathrm{m}^{-2}\right)\end{array}$} \\
\hline $\mathrm{ct}$ & $1336 \pm 93$ & $1095 \pm 52$ & $1585 \pm 88$ & $101 \pm 5$ & $86 \pm 5$ & $202 \pm 7$ \\
\hline cT & $1457 \pm 167$ & $1336 \pm 130$ & $1848 \pm 261$ & $113 \pm 20$ & $89 \pm 11$ & $189 \pm 19$ \\
\hline $\mathrm{Ct}$ & $1068 \pm 91$ & $931 \pm 112$ & $1368 \pm 172$ & $104 \pm 16$ & $82 \pm 7$ & $188 \pm 18$ \\
\hline CT & $1489 \pm 162$ & $1242 \pm 89$ & $1937 \pm 287$ & $140 \pm 18$ & $110 \pm 11$ & $262 \pm 37$ \\
\hline$c t-i$ & $1606 \pm 27$ & $1533 \pm 71$ & $1638 \pm 164$ & $142 \pm 8$ & $136 \pm 13$ & $210 \pm 21$ \\
\hline \multicolumn{7}{|c|}{ ANOVA P-values } \\
\hline $\mathrm{CO}_{2}$ & 0.31 & 0.20 & 0.59 & 0.39 & 0.40 & 0.31 \\
\hline Temp & 0.06 & 0.02 & 0.08 & 0.19 & 0.12 & 0.28 \\
\hline $\mathrm{CO}_{2} \times$ Temp & 0.21 & 0.52 & 0.41 & 0.36 & 0.15 & 0.08 \\
\hline Irrigation & 0.04 & 0.001 & 0.86 & 0.004 & 0.004 & 0.88 \\
\hline
\end{tabular}


Table S4 Average N and P pools on PRS-probes (2007 and 2009) and N:C, P:C and N and P pools in microbial biomass (2009)

\begin{tabular}{|c|c|c|c|c|c|c|c|c|}
\hline \multirow[t]{3}{*}{ Treatment } & \multirow{2}{*}{\multicolumn{2}{|c|}{$\begin{array}{l}\text { PRS-probes } \\
\mathrm{N} \text { pool } \\
\left(\mu \mathrm{g} 10 \mathrm{~cm}^{-2} \text { month }^{-1}\right)\end{array}$}} & & & \multicolumn{4}{|c|}{ Microbial biomass } \\
\hline & & & \multicolumn{2}{|c|}{$\begin{array}{l}\text { P pool } \\
\left(\mu \mathrm{g} 10 \mathrm{~cm}^{-2} \mathrm{month}^{-1}\right)\end{array}$} & \multirow{2}{*}{$\begin{array}{l}N: C \\
2009\end{array}$} & \multirow{2}{*}{$\begin{array}{l}P: C \\
2009\end{array}$} & \multirow{2}{*}{$\begin{array}{l}\mathrm{N} \text { pool } \\
\left(\mathrm{g} \mathrm{m}^{-2}\right) \\
2009\end{array}$} & \multirow{2}{*}{$\begin{array}{l}\text { P pool } \\
\left(\mathrm{g} \mathrm{m}^{-2}\right) \\
2009\end{array}$} \\
\hline & 2007 & 2009 & 2007 & 2009 & & & & \\
\hline $\mathrm{ct}$ & $14.5 \pm 0.9$ & $2.0 \pm 0.2$ & $1.35 \pm 0.13$ & $1.62 \pm 0.28$ & $0.094 \pm 0.001$ & $0.040 \pm 0.001$ & $8.31 \pm 0.93$ & $3.29 \pm 0.45$ \\
\hline cT & $26.3 \pm 5.5$ & $8.8 \pm 2.9$ & $2.20 \pm 0.36$ & $1.13 \pm 0.23$ & $0.087 \pm 0.002$ & $0.029 \pm 0.002$ & $8.59 \pm 0.84$ & $2.86 \pm 0.23$ \\
\hline $\mathrm{Ct}$ & $5.4 \pm 1.3$ & $1.5 \pm 0.5$ & $0.85 \pm 0.09$ & $1.24 \pm 0.32$ & $0.098 \pm 0.001$ & $0.038 \pm 0.001$ & $9.67 \pm 0.94$ & $3.75 \pm 0.35$ \\
\hline CT & $13.6 \pm 4.7$ & $2.3 \pm 0.9$ & $2.14 \pm 0.65$ & $1.66 \pm 0.30$ & $0.098 \pm 0.003$ & $0.038 \pm 0.003$ & $8.72 \pm 0.89$ & $3.28 \pm 0.21$ \\
\hline$c t-i$ & $5.7 \pm 1.9$ & $1.9 \pm 0.3$ & $1.77 \pm 0.42$ & $1.49 \pm 0.33$ & $0.093 \pm 0.003$ & $0.038 \pm 0.003$ & $7.73 \pm 0.67$ & $3.15 \pm 0.32$ \\
\hline \multicolumn{9}{|l|}{$\begin{array}{l}\text { ANOVA P- } \\
\text { values }\end{array}$} \\
\hline $\mathrm{CO}_{2}$ & 0.0009 & 0.04 & 0.46 & 0.80 & 0.06 & 0.18 & 0.18 & 0.17 \\
\hline Temp & 0.009 & 0.03 & 0.01 & 0.91 & 0.40 & 0.02 & 0.53 & 0.04 \\
\hline $\mathrm{CO}_{2} \times \mathrm{Temp}$ & 0.63 & 0.07 & 0.57 & 0.13 & 0.29 & 0.02 & 0.26 & 0.77 \\
\hline Irrigation & 0.02 & 0.75 & 0.36 & 0.77 & 0.85 & 0.59 & 0.63 & 0.80 \\
\hline
\end{tabular}

